\title{
PEMETAAN POTENSI WAKAF PRODUKTIF DI KOTA PEKANBARU
}

\author{
Daharmi Astuti ${ }^{1}$, Boy Syamsul Bakhri ${ }^{2}$, Masrayanti ${ }^{3}$ \\ ${ }^{1,2,3}$ Fakultas Agama Islam, Pekanbaru, Riau, Indonesia \\ e-mail:daharmi_astuti@fis.uir.ac.id
}

\begin{abstract}
This research is motivated by the lack of full implementation of productive endowments in Pekanbaru and the lack of management of productive waqf in Pekanbaru. The purpose of this study was to determine and analyze Productive Waqf Mapping in Pekanbaru. The theoretical framework used is Mapping theory with indicators of data collection stages, data presentation stages, and data use settings. The research method used is descriptive qualitative with data collection techniques using observation, interviews, documentation, literature study. The sample used is the saturated sample, the agency responsible for Productive mapping Waqf. This study indicates that Productive Waqf in Pekanbaru City has not been appropriately implemented due to the lack of people in productive earning and government participation to further optimize the empowerment of Waqf in Pekanbaru City in general. As for the Constraints and Obstacles of the Ministry of Religion in the process of Supervising Institution of Waqf in Pekanbaru City are: firstly, the lack of socialization budget for Productive Waqf, Secondly the Lack of Human Resources in managing Productive Waqf, Third Communities still think consumptive to be representative, fourth which became a reference in the city of Pekanbaru.
\end{abstract}

Keywords: Mapping, Potential, Waqf, Islamic Economic

\begin{abstract}
ABSTRAK
Penelitian ini dilatarbelakangi oleh kurangnya implementasi wakaf produktif di Pekanbaru serta adanya informasi tentang beberapa kasus baik di media cetak dan elektronik tentang kurangnya pengelolaan wakaf produktif di pekanbaru. Kebangkitan wakaf sangat penting karena memiliki potensi besar dalam membantu pertumbuhan ekonomi di Pekanbaru. Tujuan penelitian ini adalah untuk mengetahui dan menganalisis Pemetaan wakaf produktif di pekanbaru.kerangka kerja teoritisyang digunakan adalah teori pemetaan dengan indikator tahapanpengumpulan data, tahap presentasi data dan tahap penggunaan data. Metode penelitian yang digunakan adalah teknik pengumpulan data deskriptif kualitatif, menggunakan metode observasi, wawancara, dokumentasi dan studi literatur. Sampel yang digunakan adalah sampel jenuh, lembaga yang bertanggung jawab untuk Pemetaan wakaf Produktif. Hasil penelitian ini menunjukkan bahwa wakaf Produktif di Kota Pekanbaru belum dilaksanakan dengan baik karena kurangnya orang dalam representasi produktif dan partisipasi pemerintah untuk lebih mengoptimalkan pemberdayaan wakaf di Kota Pekanbaru secara umum. Kendala dan Hambatan Kementerian Agama dalam proses pengawasan lembaga wakaf di Kota Pekanbaru adalah: pertama, kurangnya sosialisasi anggaran untuk wakaf produktif. Kekurangan kedua sumber daya manusia untuk mengelola wakaf Produktif.Ketiga, orang masih berpikir konsumtif untuk mewakili.Keempat, tidak ada contoh wakaf produktif yang dirujuk di Kota Pekanbaru.
\end{abstract}

Kata Kunci: Pemetaan, Potensi, wakaf, Ekonomi Islam

\begin{tabular}{|c|c|c|c|}
\hline $\begin{array}{c}\text { FIRST RECEIVED: } \\
\text { 29 July } 2020\end{array}$ & REVISED: & ACCEPTED: & PUBLISHED: \\
28 October 2021 & 28 October 2021 & 31 October 2021 \\
\hline
\end{tabular}

\section{PENDAHULUAN}

Pemahaman dan pemberdayaan harta wakaf di kalangan umat Islam telah mengalami perubahan yang signifikan, baik dalam tataran paradigma wakaf yang awalnya hanya dipahami sebatas pemanfaatan tempat

peribadatan yang berbentuk masjid, saat ini mulai merambah ke dalam upaya pemanfaatan berbagai barang atau benda yang memiliki muatan ekonomi produktif. Sementara pada tataran praktik wakaf kini mulai dikembangkan menjadi bentuk pemanfaatan yang bernilai produktif dan sebagai salah satu

Daharmi Astuti, Boy Syamsul Bakhri, Masrayanti Pemetaan Potensi wakaf Produktif di Kota Pekanbaru 
sarana peningkatan ekonomi, seperti wkaf produktif untuk pendidikan, rumah sakit dan lain-lain. (Kasdi, 2014: 1).

Secara historis, wakaf memainkan peran ekonomi dan sosial yang penting dalam sejarah Islam. wakaf berfungsi sebagai sumber pendanaan untuk masjid, sekolah, rumah sakit, layanan sosial dan pertahanan, yaitu sebelum kemerdekaan Indonesia, karena Indonesia pernah berdiri kerajaan Islam. wakaf dalam kaitan dengan masalah sosial ekonomi harus dikelola secara produktif sehingga dapat berkontribusi untuk meningkatkan kesejahteraan dan membatu pemerintah dalam meningkatkan kesejahteraan dan standar hidup masyarakat (Sulistiani, 2017: 2).

Dasar hukum wakaf di Indonesia adalah UU No 41Tahun 2006 tentang wakaf dan peraturan Pemerintah No 42 tahun 2006 tentang penenrapan UU No 41 Tahun 2004 tentang wakaf. Pada dasarnya, wakaf produktif adalah upaya meningkatkan fungsi wakaf agar dapat memenuhi kebutuhan mereka yang berhak menerima manfaatnya. Dengan terpenuhinya kebutuhan para pihak, berarti wakaf dalam batas-batas tertentu telah berfungsi untuk meningkatkan kesejahteraan masyarakat. Dalam UUD 1945 (bab XIV) ada bab khusus tentang kesejahteraan sosial (sebelum amandemen), dan diubah menjadi ekonomi nasional dan kesejahteraan sosial yang terdiri dari dua pasal. Karena itu, wakaf dalam dimensi wakaf produktif untuk meningkatkan kesejahteraan rakyat tidak lepas dari konstitusi negara yang berlaku. Dalam konstitusi dapat dipahami bahwa wakaf harus digunakan untuk kegiatan ekonomi (memenuhi kebutuhan hidup) yang menghasilkan kesejahteraan. Dalam arti tertentu, kegiatan ekonomi adalah salah satu media untuk mencapai kesejahteraan. (Jaih Mubarok, 2008: 17).
Perkembangan wakaf di Indonesia masih belum tersosialisasikan dengan baik. Berdasarkan data Badan wakaf Indonesia (BWI) potensi asset wakaf pertahun mencapai Rp. 2000 triliun dengan luas tanah wakaf mencapai 420.000 hektare. Sementara potensi wakaf uang bisa menembus kisaran Rp. 188 triliun pertahun. Namun potensi wakaf yang terealisasi saat ini baru pada kisaran Rp. 400 miliar. Dari gambaran data tersebut dapat dikatakan wakaf produktif memiliki potensi yang sangat besar untuk membantu pertumbuhan ekonomi di Indonesia. Hal ini menjadi acuan bagi kota Pekanbaru khususnya dalam memberdayakan wakaf produktif untuk membantu pertumbuhan ekonomi di kota Pekanbaru.

Masalahnya kemudian adalah apa yang menyebabkan kurangnya kemauan masyarakat untuk memberdayakan wakaf produktif karena kurangnya sosialisasi yang maksimal terutama mengenai wakaf produktif serta kurangnya pengetahuan publik dan institusi wakaf yang dapat di percaya untuk mengelola wakaf secara kompeten. Sebab, pelaksanaan wakaf produktif saat ini tidak berjalan dengan baik, karena peran pemerintah yang kurang optimal, yang dalam hal ini dibantu oleh sejumlah BWI (Badan wakaf Indonesia) yang dikoordinasikan oleh Pemerintah masingmasing daerah sehingga memengaruhi partisipasi masyarakat terhadap wakaf.

Pemetaan adalah proses pengumpulan data yang akan digunakan sebagai langkah pertama membuat peta dengan menggambarkan distribusi spasial kondisi alam tertentu, memindahkan situasi aktual ke dalam peta dasar yang diekspresikan dengan menggunakan skala peta dengan mempertimbangkan potensi geografis, sumber daya alam, manusia sumber daya dan potensi budaya. Dalam memfasilitasi proses pemetaan 
ini ada beberapa tahapan yang harus dilakukan dalam perancangan peta.

Proses pemetaan dilakukan dalam tiga tahap; 1) pengumpulan data. Pemetaan dimulai dengan pengumpulan data. Keberadaan data sangat penting, dengan data seseorang dapat melakukan analisis evaluasi tentang area data tertentu.Data yang dipetakan dapat berupa data primer atau data sekunder. Data yang dapat dipetakan adalah data khusus, artinya data tersebut didistribusikan atau didistribusikan ke sebuah ruangan di area tertentu. Pada tahap ini data yang telah terkumpul kemudian dikelompokkan berdasarkan jenisnya seperti kelompok data kualitatif atau data kuantitatif. (Intan Permanasari, 2007). 2) Penyajian data. Tahap ini merupakan upaya melukiskan atau menggambarkan data dalam bentuk simbol, supaya data tersebut menarik, mudah dibaca dan dimengerti oleh pengguna (users). Penyajian data dalam sebuah peta harus dirancang secara baik dan benar supaya tujuan pemetaan dapat tercapai. 3) penggunaan peta merupakan tahap penting karena menentukan keberhasilan pembuatan suatu peta. Peta yang dirancang dengan baik akan dapat digunakan/dibaca dengan mudah. Peta merupakan alat untuk melakukan komunikasi, sehingga pada peta harus terjalin interaksi antar pembuat pata (map maker) dengan pengguna peta (map user). Pembuat peta harus dapat merancang peta sedemikian rupa sehingga peta mudah dibaca, di interprestasi, dan dianalisis oleh pengguna peta. Pengguna harus dapat membaca peta dan memperoleh gambaran informasi sebenarnya dilapangan (Rial Word).

Elpina (2017) mengatakan bahwa Perkembangan tanah wakaf di indonesia sangat berpotensi untuk pertumbuhan ekonomi di indonesia Sedangkan Devi Megawati (2015) dalam penelitiannya menyatakan bahwa hasil pengelolaan dan pengembangan wakaf produktif di kota Pekanbaru masih sederhana dengan menajemen tradisional.

Dari latar belakang inilah peneliti memandang perlu untuk melakukan sebuah pemetaan tentang potensi wakaf di pekanbaru, di samping data ini di perlukan oleh para pengambil kebijakan dan para peneliti tentang wakaf di Pekanbaru untuk ke depannya.

\section{METODE PENELITIAN}

Jenis penelitian ini adalah penelitian lapangan dengan menggunakan metode deskriptif kualitatif. Sampel yang digunakan dalam penelitian ini sampel jenuh, yang merupakan penentuan sampel yang digunakan semua anggota populasi sebagai sampel (Beni Ahmad Saebeni, 2008). Dimana populasi adalah lembaga yang bertanggung jawab untuk pemetaan wakaf Produktif, sampel yang dilakukan dalam penelitian ini adalah mereka yang mengelola wakaf Produktif di Kota Pekanbaru.

Metode pengumpulan data adalah metode observasi, wawancara (wawancara) dan dokumentasi. Metode analisis data yang digunakan untuk memeriksa kondisi bendabenda alam, (bukan sebagai eksperimen), yaitu, penelitian adalah instrumen kunci, teknik pengumpulan data dilakukan dengan triangulasi (gabungan), analisis data bersifat induktif dan hasil penelitian kualitatif lebih menekankan makna daripada generalisasi.

\section{HASIL DAN PEMBAHASAN}

Pemberdayaan wakaf di $\begin{array}{r}\text { Kota } \\ \text { Pekanbaru sebagaimana yang }\end{array}$
tiungkapkan oleh Kementerian Agama Kota
Pekanbaru bahwa Potensi wakaf Produktif di
wilayah Kota Pekanbaru sangat luar biasa
Potensinya melihat antusias masyarakat dari
tahun ke tahun ada peningkatan dalam
berwakaf sebagaimana yang terdata pada
sistem Siwak Kementrian Agama Kota
106

Daharmi Astuti, Boy Syamsul Bakhri, Masrayanti Pemetaan Potensi wakaf Produktif di Kota Pekanbaru 
Pekanbaru tapi sangat disayangkan kebanyakan masyarakat Kota Pekanbaru hanya berwakaf dalam bentuk wakaf konsumtif bukan dalam bentuk wakaf produktif dan strategi Kementerian agama dalam mengoptimalkan wakaf Produktif seperti yang telah disampaikan oleh Kasi Syariah di Kementrian Agama Kota Pekanbaru disebabkan kurangnya sosialisasi kepada masyarakat serta anggaran pemerintah pusat untuk memberdayakan pelaksanaan wakaf produktif kemudian karena kurangnya SDM yang mampu memberdayakan wakaf produktif.

Sistem perizinan wakaf di kota Pekanbaru pengurusan langsung melalui KUA seluruh Indonesia. Jumlah wakaf produktif yang terdaftar secara resmi di Kementerian agama kota Pekanbaru tidak ada sedangkan 1068 wakaf tidak Produktif hanya dalam berbentuk tempat ibadah dan sosial saja. Setiap tahun animo masyarakat dalam berWakaf semakin meningkat tetapi sangat disayangkan hanya dalam bentuk wakaf konsumtif saja bukan yang produktif. Dalam hal ini masyarakat paling banyak berwakaf hanya pada tempat ibadah seperti mesjid $41,5 \%$ dan musholla 28\%. Kementerian Agama rutin melakukan pengawasan terhadap Perkembangan wakaf Produktif dua kali sebulan di Kota Pekanbaru. Kementerian Agama Rutin dalam mensosialisasikan wakaf Produktif melalui Televisi, web aplikasi siwak, radio dan Lembaga Dakwah supaya banyak masyarakat yang antusias dalam berwakaf sehingga dapat membantu meningkatkan pertumbuhan ekonomi di Kota Pekanbaru. Lembaga wakaf melaporkan dana wakaf yang terkumpul Pertahun kepada Kementerian Agama Kota Pekanbaru per enam bulan sekali inipun banyak nazhir yang tidak melaporkan.

Tabel 1.
Jumlah Tanah wakaf Di Kota Pekanbaru

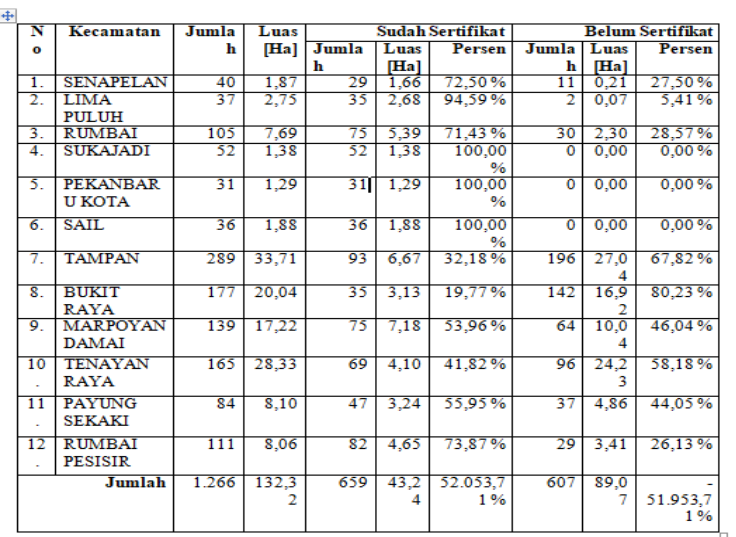

Berdasarkan data dari tabel di atas, dapat dilihat bahwa Jumlah harta wakaf yang paling banyak terkonsentrasi pada tanah sebanyak 177 lokasi dengan luas 20,04 Ha di Kabupaten Bukit Raya. sedangkan alokasi wakaf tanah paling sedikit adalah 31 lokasi dengan luas 1,29 $\mathrm{Ha}$ di Kabupaten Kota Pekanbaru. Lahan wakaf terbanyak yang telah disertifikasi adalah $93 \mathrm{Ha}$ seluas 6,67 $\mathrm{Ha}$ dengan persentase $32,18 \%$ sedangkan yang paling sedikit $29 \mathrm{Ha}$ lokasi adalah 1,66 Ha dengan persentase $72,50 \%$. Tanah wakaf yang paling tidak tersertifikasi adalah 196 lokasi dengan luas 27,04 Ha dengan persentase $67,82 \%$, sedangkan setidaknya 2 lokasi dengan luas 0,07 Ha dengan persentase 5,41\% tentang jumlah aset tanah wakaf di Kota Pekanbaru.

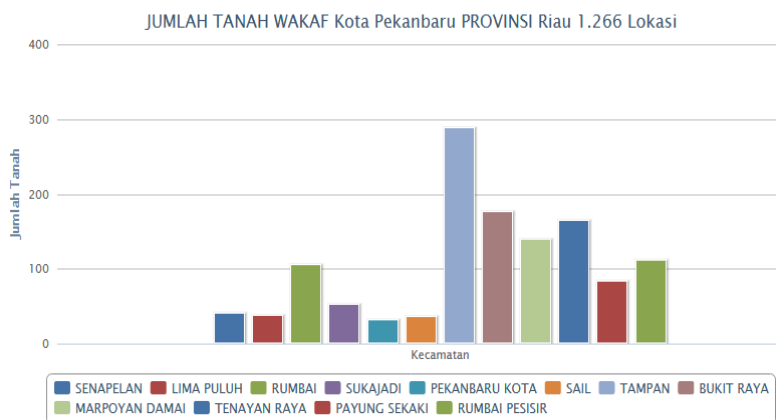

Gambar 1. Jumlah Tanah wakaf Kota Pekanbaru Provinsi Riau 1.266 Lokasi

Berdasarkan dari data tabel grafik diatas terlihat yang paling banyak Jumlah harta wakaf tertumpu pada tanah sebanyak 177 lokasi Di Kecamatan Bukit Raya. Sedangkan yang paling sedikit peruntukan tanah wakaf 
sebanyak 31 lokasi di Kecamatan Kota Pekanbaru.

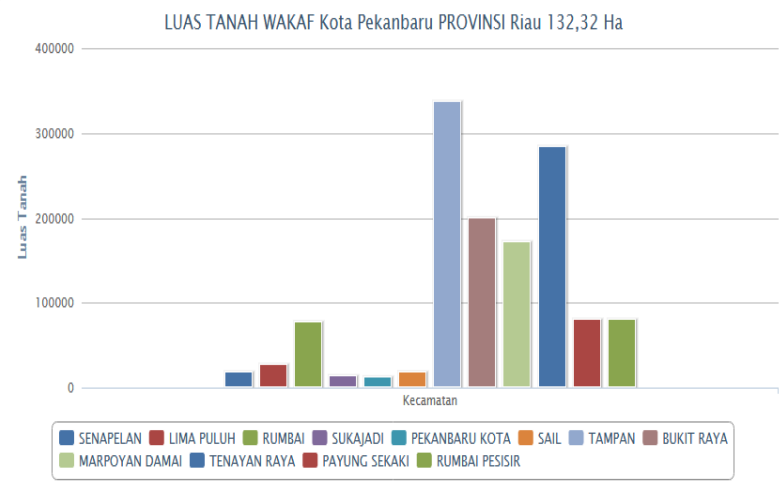

Gambar 2. Luas Tanah wakaf Kota Pekanbaru Provinsi Riau 132,32 Ha

Berdasarkan dari data tabel grafik diatas terlihat yang paling banyak Jumlah harta wakaf tertumpu pada tanah sebanyak 20,04 Ha di Kecamatan Bukit Raya. sedangkan yang paling sedikit peruntukan tanah wakaf sebanyak 1,29 Ha di Kecamatan Kota Pekanbaru. Adapun data peruntukanWakaf di kota Pekanbaru tahun 2019 yang terdapat pada tabel dibawah ini:

Tabel 2.

Data Peruntukan WakafKementrian Agama di Kota Pekanbaru

\begin{tabular}{|c|c|c|c|c|c|c|c|}
\hline \multirow[b]{2}{*}{$\begin{array}{c}\text { KAB/ } \\
\text { KOTA/KEC }\end{array}$} & \multicolumn{7}{|c|}{ PERUNTUKAN WAKAF } \\
\hline & $\begin{array}{l}\text { Tempat } \\
\text { Ibadah }\end{array}$ & $\begin{array}{c}\text { Sekolah/ } \\
\text { Madrasah }\end{array}$ & Ponpes & Usaha & Makam & $\begin{array}{c}\text { Panti } \\
\text { Asuha } \\
\text { n }\end{array}$ & $\begin{array}{l}\text { Lain- } \\
\text { Lain }\end{array}$ \\
\hline$I$ & 2 & 3 & 4 & 5 & 6 & 7 & 8 \\
\hline Kota Pekanbaru & & & & & & & \\
\hline Rumbai & 63 & 10 & 2 & & 5 & & 3 \\
\hline Rumbai Pesisir & 70 & 11 & & & 4 & & 1 \\
\hline Limapuluh & 33 & & & & 2 & & \\
\hline Pekanbaru Kota & 19 & 3 & & & & & \\
\hline Sukajadi & 44 & & & & & & 1 \\
\hline Sail & 20 & 1 & & & & & 1 \\
\hline Tampan & 157 & 19 & 3 & & 1 & 1 & 11 \\
\hline Payung Sekaki & 57 & 19 & & & & & 2 \\
\hline Bukit Raya & 131 & 3 & & & 5 & & 2 \\
\hline $\begin{array}{l}\text { Marpoyan } \\
\text { Damai }\end{array}$ & 107 & 3 & 2 & & 6 & & \\
\hline Tenayan Raya & 82 & 9 & 7 & & 12 & & 7 \\
\hline Senapelan & 40 & & & & & & \\
\hline Jumlah & 823 & 78 & 14 & & 35 & 1 & 28 \\
\hline
\end{tabular}

Sumber: KUA Kecamatan se Kota Pekanbaru 2019

Berdasarkan dari data diatas terlihat mayoritas peruntukan hartaWakaf tertumpu pada tempat ibadah sebanyak 823 buah dan di ikuti dengan mayoritas kedua untuk sekolah/madrasah sebanyak 78 buah, kemudian peruntukan wakaf untuk mayoritas ketiga untuk makam sebanyak 35 buah dan peruntukan wakaf untuk panti asuhan hanya 1 buah, sedangkan peruntukan wakaf untuk usaha yang bersifat produktif temuan lapangan ada 5 mengenai harta wakaf yang berhasil dikelola menjadi produktif telah ada di Kota Pekanbaru yaitu:

Tabel 3.

Pemanfaatan Aset wakaf Produktif di Kota Pekanbaru 2019

\begin{tabular}{|c|c|c|c|}
\hline Nama & Alamat & $\begin{array}{c}\text { Peruntukan } \\
\text { Tanah Wakaf } \\
\text { Lainnya }\end{array}$ & $\begin{array}{c}\text { Hasil Dari Peruntukan } \\
\text { Tanah Wakaf Produktif }\end{array}$ \\
\hline $\begin{array}{c}\text { Masjid A1- } \\
\text { Falah II }\end{array}$ & $\begin{array}{c}\text { J1. Murai Kec. } \\
\text { Sukajadi }\end{array}$ & $\begin{array}{c}\text { Rumah kos-kosan } \\
\text { da gedung MDA }\end{array}$ & $\begin{array}{c}\text { Membayar guru honor } \\
\text { MDA. }\end{array}$ \\
\hline $\begin{array}{c}\text { Baitul } \\
\text { Mukminin }\end{array}$ & $\begin{array}{c}\text { J1. Ababil Kec. } \\
\text { Sukajadi }\end{array}$ & Rumah kontrakan & $\begin{array}{c}\text { Membayar guru honor } \\
\text { MDA. }\end{array}$ \\
\hline Al Khairat & $\begin{array}{c}\text { J1.Mangag Kec. } \\
\text { Sukajadi }\end{array}$ & Ruko & $\begin{array}{c}\text { Melunasi cicilan } \\
\text { pembangunan ruko. }\end{array}$ \\
\hline $\begin{array}{c}\text { Masjid } \\
\text { Muslimin }\end{array}$ & $\begin{array}{c}\text { J1. Ahmad Yani } \\
\text { Kec. Marpoyan } \\
\text { Damai }\end{array}$ & Rumah Kontrakan & $\begin{array}{c}\text { Memberi honor guru } \\
\text { MDA dan membavar } \\
\text { biaya operasional masjid } \\
\text { dan Sebagian lagi } \\
\text { membayar cicilan rumah } \\
\text { kontrakan. }\end{array}$ \\
\hline $\begin{array}{c}\text { Masjid An } \\
\text { Najah }\end{array}$ & $\begin{array}{c}\text { J1. Imam } \\
\text { Munandar Kec } \\
\text { Bukit Raya }\end{array}$ & Rumah kontrakan & $\begin{array}{c}\text { Membantu membiayai } \\
\text { operasional MTS. An - } \\
\text { Najah dan MDA }\end{array}$ \\
\hline
\end{tabular}

Dapat kita lihat dari tabel Pemanfaatan wakaf bahwa pelaksanaan wakaf Produktif yang telah terlaksana ada 5 di Kota Pekanbaru secara mandiri. Maka dapat disimpulkan bahwa wakaf Produktif di Kota Pekanbaru belum optimal karena kurangnya masyarakat dalam berwakaf secara produktif serta partisipasi pemerintah untuk lebih mengoptimalkan pemberdayaan wakaf di Kota Pekanbaru umumnya.

\section{SIMPULAN}

Pelaksanaan wakaf di kota Pekanbaru masih bersifat konsumtif ketimbang produktif. Pelaksanaan wakaf produktif baru terbatas pada lima aset di Kota Pekanbaru dari 1068 aset wakaf. Maka dapat disimpulkan bahwa wakaf produktif di kota Pekanbaru belum terlaksana dengan baik karena kurangnya masyarakat dalam berwakaf secara produktif serta partisipasi pemerintah untuk lebih mengoptimalkan pemberdayaan wakaf di kota Pekanbaru umumnya. Adapun Kendala dan hambatan Kementerian Agama dalam proses

Daharmi Astuti, Boy Syamsul Bakhri, Masrayanti Pemetaan Potensi wakaf Produktif di Kota Pekanbaru 
pengawasan lembaga wakaf di Kota Pekanbaru adalah: 1) Minimnya anggaran sosialisasi untuk wakaf khususnya wakaf produktif, 2) Minimnya Sumber Daya Manusia yang menguasai bidang dalam mengelola wakaf Produktif, 3) Masyarkat masih berfikir konsumtif untuk berwakaf, 4)Belum muncul contoh wakaf produktif yang menjadi rujukan dan acuandi kota Pekanbaru.

Dalam rangka mengembangkan wakaf secara produktif diperlakukan hal sebagai berikut: Perlu adanya dukungan pemerintah untuk mengalokasikan anggaran operasional yang memadai dalam pengelolaan wakaf; Perlu adanya Sumber Daya Manusia yang kompeten dalam bidang wakaf; Perlu sosialisasi oleh tokoh agama, pmerintah dan tokoh masyarakat urgensi dan peran wakaf dalam meningkatkan kesejahteraan ekonomi; Perlu adanya contoh atau model rujukan dalam pelaksanaan wakaf produktif di kota Pekanbaru.

\section{DAFTAR PUSTAKA}

Direktur Pemberdayaan wakaf. (2007). Paradigma baru wakaf di Indonesia. Jakarta: Depag RI.

Kasdi, Abdurrahman, dkk (2014). Pemberdayaan wakaf Produktif Berbasis Wirausaha. Yogyakarta: Idea Press

Kompri. (2018). Manajemen dan Kepemimpinan Pondok Pesantren. Jakarta: Pranadamedia Group.

Majelis Ulama Indonesia.(2011).Himpunan Fatwa MUI. Jakarta: Erlangga.

Mardani. (2011). Fiqih Ekonomi Syariah,wakaf.Jakarta:Kencana

Prenadamedia Group.

Mubarok, Jaih. (2008). wakaf Produktif: Paradigma wakaf Produktif. Bandung:Refika Offset.
Muhammad Azzam, Abdul Aziz. (2010). Fiqh Muamalat: sistem transaksi dalam Fiqh Islam. Jakarta: Amzah.

Muhammad.(2008).Metodelogi Penelitian Ekonomi Islam, Pendekatan Kuantitatif, $E d$. Jakarta: Rajawali Pers.

Nawawi, Ismail. (2012). Fiqh Muamalah: klasik dan kontemporer. Bogor: Ghalia Indonesia.

Qahaf, Mundzir. (2008). Manajemen wakaf Produktif: Sejarah Pemikiran wakaf.

Rozalinda.(2016). Manajemen wakaf Produktif. Jakarta: Rajawali Press

Saidi Zaim. (2013). Mengoptimalkan wakaf: dari Liability ke Asset Management.akses 15 April.

Sanusi, Anwar. (2011). Metode Penelitian Bisnis. Jakarta: Salemba Empat.

Suhendi, Hendi. (2014). Fiqh Muamalah:wakaf. Jakarta: Rajawali.

Usman, Rachmadi. (2013). Hukum Perwakafan di Indonesia. Jakarta: Sinar Grafika.

Walgio, Bimo. (2002). Psikologi Sosial.Yogyakarta: Andi offset. 